\title{
Nigeria: a federation gone wrong
}

\author{
J.F. Kirsten \\ Department of Political Sciences \\ Potchefstroom University for CHE \\ POTCHEFSTROOM
}

\begin{abstract}
Nigeria: a federation gone wrong

Due to its size, large population, oil-based economy and geographical location in West Africa. Nigeria is regarded as an important state in Africa. The country is also one of the longest surviving federal states on the continent and therefore represents an ongoing experiment in federalism in the Third World. Since its independence in 1960, however. Nigeria has been devastated by chronic political instability. This article tries to address the issue why this is the case and to identify ethnic-religious diversity and successive military regimes as the most important sources for the mentioned political unrest. The course and nature of political instability in Nigeria is put in historical context - a context which also include the secession attempt by Biafra as one of the tragic highlights in the past of Nigeria. In conclusion, the author speculates on ways and options as to how secession attempts can be prevented and a larger amount of national political slability be achieved.
\end{abstract}

\section{Introduction}

Nigeria gained independence on 1 October 1960. The three and a half decades which have elapsed since, represent a particularly troubled period of intense political competition, military coup d'états, general instability of government and a long, expensive and bitter civil war. During this period, the country experienced nine different governments, two civil and seven military ones, lasting on the average for a period of less than four years (Ake, 1993:639). All these events were accompanied by a deteriorating economical situation. At present, Nigeria is burdened with a debt of more than 37 billion dollars and an inflation rate of 70 percent (Anon., 1995a:36).

This situation immediately raises the following questions: how could such a situation have been possible and what explanations could be provided for it? It is clear that the attainment of formal political independence has not resulted in an awareness of national political unity in the country. The achievement of peace and stability as well as political continuity still eludes Nigeria. 
Successive Nigerian governments have then attempted to harmonize state sovereignty (the exclusive authority governments exert in independent states) with national unity and awaken an awareness within the Nigerian population. A purposive attempt has for instance been made to redress the lack of unity in the country as part of an ongoing process. One of the results of this attempt has been that existing state boundaries have been maintained at all costs and that no secession of any ethnic group has even been considered.

Indications are that the essence of this problem is located in the concept of the nation state which presupposes that the citizens of states regard themselves as a unity with a communal loyalty towards the government and the geographical area that the state occupies. In many instances this is not the case, especially in Africa where the majority of states are multi-ethnic in composition (Papp, 1988:19). In such cases, the nation does not reflect the state in the practical sense - a phenomenon which creates a basis for political instability and incurs secession claims by specific ethnic groups in existing states (Liebenow, 1986:45). In this way, the question of national self-determination is constantly foregrounded in international politics. For the purposes of this article self-determination is interpreted as a principle of freedom for ethnic or religious groups constituting minorities in sovereign states (Cassese, 1993:823).

In order to accommodate the geographical, ethnic, religious and political diversity in Nigeria and to try to accomplish national unity, the country instituted a federal political system from the very beginning. It is therefore the aim of this article to consider to what extent the federation has been successful and what the practical circumstances and limitations relating to the Nigerian situation have been. The possibility of some new factors which emerged during the last 36 years of independence is also considered. First of all, the focus will be placed on the above-mentioned population diversity and the attention will then shift to a brief perspective on the political history of the Nigerian federation. The Christian view concerning authority and justice is also touched upon. In conclusion, a reasonable assessment of the defects of and possible remedies for this leading state in West Africa is given.

\section{The ethno-religious diversity of Nigeria}

As far as its ethnic diversity and heterogeneity are concerned, Nigeria is a typical African state. The country's tctal population of about 105 million people can be divided into about 250 ethnic groups (Ake, 1993:639). The most important of these groups are the Hausa and Fulani in the north, the Joruba in the west and the Ibo in the east. These four groups represent about seventy-five percent of the total population. Other small ethnic groups are the Ijaws in the Riverine Area, the Itshekiris, Urhobos, Efiks and Ibibios in the south (where elements of the Ibo and Joruba also exist), the Igalas, Nupes, Idomas and Tivs in the Middle Belt, 
and the Kanuris and Jukuns (together with the Hausa and the Fulani) in the north (Commonwealth Secretariat, 1995:315).

More than two hundred languages are spoken, with Hausa, Joruba and Ibo as the main languages, while English serves as the official language. It is interesting to note that, in terms of ethnic and language homogeneity, Nigeria ranked seventh on the world list in the late seventies with 13 percent on a scale, whereas North and South Korea occupied the 135 th place with 100 percent homogeneity and Tanzania in the first place with 7 percent (Kurian, 1978:1083).

In addition to the above-mentioned ethnic diversity, there is also evidence of religious differences which tend to enforce and emphasize ethnic diversity. Nigeria represents the most southem tip of the Islamic sphere of influence which was predominant in North Africa from the 10th till the 19th century. The penetration of this Islamic influence had, however, been stopped before it could reach the southern part of the country. On the other hand, Christianity has become well established in southern Nigeria but has not been able to expand into the northern and western parts (Kurian, 1978:1083). Consequently, the religious composition of the population is closely related to the geographical and ethnic lines of distribution: the southern Ibo are predominantly Christian, while the northern Hausa are totally Muslim-oriented and the western Joruba are part Christian and part Muslim in composition.

According to statistics of 1987 about 45 percent of all Nigerians were Muslim, 22 percent were Christians and the rest were followers of animistic African religions (Graf, 1988:6). It has already been proven on various occasions that these differences in religion have contributed to political and social unrest (Anon., 1984:236). Furthermore, hardly any doubt could exist that the Biafran civil war (1967-1970) also contained undertones of religious differences, but more specifically, it resulted from the differences between Christian-Ibos and Muslim Hausa/Fulani.

The impact of the already mentioned ethnic and religious differences on the political life of the Nigerian state was far reaching from the beginning and still represents one of the single largest obstacles in the way of political stability. There seems to be little doubt that, as far as Nigeria is concerned, ethnicity has retained its relevance as a mechanism of analysis in the course of time. Segal (1979:7) concludes that "... although ethnicity is a far older basis of organization than either the nation-state or systems of rank based more on classes and less on status group, it does not lose its salience as these other forms developed around it". 
Nigeria: A federation gone wrong

\section{The birth of a federation in West Africa}

As is known today, Nigeria was conquered by the United Kingdom during the second half of the nineteenth and the first decade of the twentieth centuries. In 1914, North and South Nigeria were united by the British government and administered as one state. Despite the fact that a legislative council was formed in 1922 to rule this area, the administration mostly remained in the hands of traditional indigenous leaders but under the supervision of the colonial authority (McCaskie, 1995:693). This indigenized style of rule formed the basis of the federal dispensation which was later instituted. It is significant that this indirect system of rule was reasonably successful in the north, but in the west (among the Jorubas) and in the south east (among the Ibos) less success was achieved. All indications are that indirect rule became unpopular among many educated Africans because of its emphasis on preserving traditional culture, excluding them from administration and the native courts (Commonwealth Secretariat, 1995:318).

Claude Ake (1993:639) points out that the British colonial policy of indirect rule (especially during the first half of the twentieth century) had been aimed at debilitating and upsetting the rise of a nationalist movement in Nigeria and according to him, this policy later also contributed towards the regionalization of the political elite as well as the politicising of national and ethnic sectionalism. Due to the geographical and ethnic lines of separation which characterized the Nigerian situation, and the tension and conflict which have emerged since the end of the nineteenth century, the British government really had no other option but to introduce a federal government system which was instituted in 1947. This government system included three areas, the Eastern, Western and Northern Regions. "The federal arrangement was an attempt to reconcile regional and religious tensions, and to accommodate the interests of Nigeria's diverse ethnic groups" (McCaskie, 1995:693).

In 1954 the federation was granted independent rule - an event which was followed by a series of constitutional conferences in an attempt to create a balance between regions and ethnic groups in the state. Very little success was achieved and it was therefore not surprising that the three main political parties involved in Nigeria's bid for independence were regionally bound and ethnically oriented: the Northem Peoples Congress (NPC) represented the Hausa in the north, the Action Group (AG) was the Joruba's party in the west and the National Council in Nigeria and the Cameroons (NCNC) was the political party of the lbo in the east (Ake, 1993:639). Within this party-political division, the undercurrents of a power struggle based on ethnic divisions were present, and directly and detrimentally affected the democratic political stability. In fact, today after 36 years of independence, there are still no relevant political parties which could successfully enlist support on a national basis (Kwarteng, 1993:30-31). 
The political situation immediately before Nigeria's independence was clearly based on kinship and ethnic groups, a fact which made the membership of political parties exclusive and absolutised political differences. In such a situation politics equates a zero sum game which is played with passion. Nigeria has confirmed it.

It was not only the British government that believed Nigeria should become independent as a federal state, but all the most important Nigerian leaders of the time were also convinced that "... a federal structure was the most viable form of state and that a unitary model would not be successful in the Nigerian context" (Motala, 1992:8). Together with the British authorities, they believed that attempts at integrating the communities would only result in a fiasco and that a federal constitution would reduce mutual antagonism. From 1960 till 1967 (The First Republic) Nigeria was a federation of three regions, and after the creation of Mid-Western Nigeria, four regions (Commonwealth Secretariat, 1995:319).

In the light of this background, the political instability which followed the independence of Nigeria was on the one hand not unexpected but on the other hand contrary to the expectations of the federal optimists. The climax was reached in 1967 with the Biafran civil war that divided the world. The federal government was supported by the Soviet Union and its allies in Eastern Europe, the OAU, the Arab states, the USA and Britain. On the other hand, Biafra reccived international recognition and support from France, Gabon, the Ivory Coast, Tanzania, Zambia, the People's Republic of China, Israel and South Africa (Marenin, 1993:79). The events preceding the war and its duration clearly demonstrate that, as a federal state, Nigeria was doomed to failure.

\section{The Biafra tragedy}

Within two years after independence, Nigeria was immersed in a political crisis The reason was the difference of opinion that occurred after the national census held in 1962. The numbers mentioned in the census were a source of conflict "... because of their potential effects on the balance of power between the major nationalities" (Ake, 1993:639). This problem was never solved. In fact, its results merely caused the national election of 11 January 1965 to develop into a constitutional crisis with large-scale civil unrest. This crisis again directly gave rise to the first military coup d'état executed mainly by lbo officers in Nigeria on 19 January 1966 . This event was shortly afterwards followed by another coup which, at that time, was led by officers from the ranks of the Hausa/Fulani in the north.

The large-scale murder and persecution of Ibo inhabitants in the north caused 1,5 million of these widely distributed lbos to flee to the south east (Biafra) and they decided to fight in an organized way for the separation and independence of 
Nigeria: A federation gone wrong

Biafra (Ake, 1993:639). When the civil war ended on 13 January 1970, between 600000 and 1,5 million people had died and the economy of the region had been destroyed.

In his commentary on the Biafran civil war, Marenin (1993:79) points out that the origin of the attempts at separation could be ascribed to "... a political structure that fragmented power among regions each dominated by a major ethnic group; traditional subnational fears and rivalries; an increasing differentiation of political and economic power among groups, regions, and classes". All indications were that the elements of ethnicity and class had created a mutually-reinforcing effect (Marenin, 1993:79).

Certainly, in the political history of Nigeria, the Biafran civil war serves as the best example of Nigeria's failure as a federal state and its inability to establish political stability as a political system. The destruction of Biafra and the Ibo were a clear warning and deterrent for other potential secessionists if they were to attempt something similar (Harden, 1993:288). For succeeding govenuments and the political military elite of Nigeria the prevention of another Biafra has become a policy guiding principle ever since (Marenin, 1993:79).

\section{New attempts at nation building: The actions of military regimes}

The immense tensions surrounding the lbo issuw both before and after the Biafran civil war had, among others, caused the federal military leaders to extend the existing four federal regions to constitute twelve states on 28 May 1967. This step was specifically aimed at creating a more even-handed treatment for geographical regions and ethnic groups and to promote the influence of the nonIbo residents in the eastem region (Anon., 1995b:647). Ten years later, in April 1976, the number of states were further increased to nineteen. This increase in the number of states had been coupled with adaptations to the Nigerian constitution in order to directly address political conflict and instability. The constitution which was promulgated on 21 September 1978 had changed the Nigerian political system from a parliamentary to a presidential one with a considerable amount of power concentration vested in the president of the Federation (Ake, 1993:639).

The 1978 constitution laid the foundation for the Second Nigerian Republic (1979-1983) and within this framework, a series of national elections were held in 1979 in which five parties participated. The result was a civil democratic dispensation that lasted till 1983 with President Shagari as federal president (Anon., 1995b:647). Since that time, Nigeria has constantly been under military rule and all attempts to re-establish a civil government have failed despite considerable international pressure. 
It is particularly instructive that the number of states in Nigeria were extended by another two under the rule of President Babangida in September 1987 to amount to 21 (the Federal Capital area excluded) and in August 1991 to 30 states "... based on 'social justice, the principle of development and the principle of a balanced federation"' (Anon., 1995b:649). The reasons which president Babangida proposed for the existence of 30 states in the Federation are not questioned as such. It should be added that this large-scale fragmentation had also been aimed at geographically dividing the larger ethnic groups in order to weaken them politically and to consolidate the position of the smaller ethnic groups. By doing this the character of ethnic conflicts has been redefined, rather than solved (Kwarteng, 1993:33).

A survey of the political instability of the Second Nigerian Republic (1979-1983) as well as the subsequent period has indicated that the causes have acquired a multi-dimensional character and could not merely be ascribed to ethnic and cultural differences. During this period, instability could increasingly be related to a distrust of the government's ability to rule effectively. The government's excessive expenditure and massive official corruption and waste were pointed out. The lessons learnt from the Biafran war were soon forgotten and the enormous income from oil, for example, was not used to benefit the whole country. Apart from this fact, the military regimes have become one of Nigeria's largest problems as they do not seem to be able to abdicate their political power at the appropriate time. The present crisis surrounding President Abacha is a clear example of how a military regime could prevent the reinstatement of democracy.

Since 1984 the military regimes lave been "taken captive", have been influenced by all the contradictions of Nigerian politics and infiltrated by ethnic, religious and regional conflict and factionalism (Ake, 1993:640). Naturally, political stability would seem impossible in suclı circumstances.

Thus far in this article an attempt was made to highlight some of the important politico-constitutional aspects in the history of Nigeria. The logical conclusion that could be drawn would be that democracy and the federal political system have failed in Nigeria, that nation building has not produced the right results; that ethnicity still remains a very important divisive factor and that it is actually surprising that no spontaneous secession attempt has been made since 1970 . The reasons for Nigeria's failure as a state and the possibility of the balkanisation of the country into more states will be discussed in the following part of the article.

Koers 6I(4) 1996:499-509 
Nigeria: A federaton gone wrong

\section{The Nigerian federation - a reflection on the reasons for its failure}

From its inception, Nigeria has been an artificially constructed state and the result of colonial power enforcement in Africa. At no stage did the Britisl government considered creating new states with homogeneous populations. The British indirect system of rule acknowledged ethnicity, and in the process feelings of nationalism were dampened by directing loyalty to the local rulers and the colonial administration (Kwarteng, 1993:24). Later on a federal political system was used in an attempt to reconcile and alleviate regional, ethnic and religious tensions and differences.

According to Smith (1987:108), the federal system in Nigeria has only succeeded in exacerbating ethnic and other differences by expressing them in permanent territorial forms, something which, in tum, led towards the maintenance of regional domination and attempted separatism (Biafra). The increasing differentiation between political and economic power between groups, areas and classes has spurred on conflict and corruption, and promoted elite competition. Against this background, it remains an open question whether the increase in the number of states has in fact succeeded in ending the domination of subunits by larger ethnic and religious groups.

The fact of the matter is that the Nigerian federal system has for a long time embodied specific ethno-cultural differences in the form of territorial protection and that phenomenon has contributed to political instability and led to the repeated mobilization of ethnic minorities. This situation contrasts sharply with a successful federation like the USA where the units (states) do not coincide with cleavages in the population (Motala, 1992:9)

Another disturbing observation with regard to Nigerian politics is that since 1960 the negative influence of ethno-religious diversity has increasingly coincided with a growing distrust within the broad ranks of the population. The population increasingly distrusted the ability of the government (civil or military) to rule effectivily. As has already been shown, this distrust is the result of large-scale corruption and the squandering of national resources by the political elite in power. These political leaders indeed proved themvelves as undisciplined and incapable of giving decisive guidance. At the same time, however, they did exploit ethnic and regional differences in order to retain political power (Ake, 1993:640).

It is indeed interesting and important to note that the phenomenon of national selfdetermination and secession is directly connected with the mentioned corruption and mismanagement by successive Nigerian govemments. Odogu (1994:165) points out this fact by showing that the founding of the Ethnic Minority Rights 
Organization of Africa (EMIROAF) was more an expression of the dissatisfaction flowing from the marginalization of some of the ethnic minority groups and the harm being done to them because of corruption on a national level. (EMIROAF is an organization founded in Nigeria. This organization propagates the establishment of states based on ethnicity within a loose federal structure and with the specific option for separation if a specific group should so desire.)

Among the Nigerian political elite little or no support exists for the balkanization of Nigeria into independent ethnic states. At present, practical considerations are playing a major role in regarding it as an unfavourable option. According to General Obassanjo, a former head of state and president of Nigeria, the interwovenness and complementarity of the various aspects of national life in Nigeria make a breakup undesirable and almost impossible (Odogu, 1994:166167). Naturally, that does not mean that the federation cannot still break up. The idea that the federation is not likely to break up is reinforced by the political hold of and the attachment to ethno-nationalism in the politics of Nigeria and the inability of the political leadership to produce sound and effective government.

A very important determining factor has appeared since 1989 - a factor which is already influencing Nigerian politics in a profound way - a democratic movement with the specific objective to get rid of Genl. Abacha and his military regime gained impetus. This movement also crossed all ethnic lines. It is against this background that one must start looking for possible solutions and options for Nigeria

\section{By way of conclusion - possible solutions and options for Nigeria}

It seems clear that only two options exist for Nigeria at this stage, namely that politics must be de-militarized and that the country must become democratic enough to consider the interests of all minority groups and the population at large. The long term solution lies in more responsive government regarding the needs of the population as a whole. Corruption and personal enrichment among the political elite of Nigeria - a phenomenon which is so extensive and widespread that the country's national interest is in jeopardy - must be brought to an end

In order to accomplish these aims an even more fundamental issue must be addressed, namely the values needed for democratic, responsible and responsive government. This fundamental issue also necessarily implies the implementing of a just and accountable government of which the political elite should be the leading proponents and supporters. If this ideal can be established as part of a value system within the political leadership it might eventually filter through to the population in general. 
Nigeria: A federation gone urong

In fact, the values that were referred to in this article represent an extraction from Christian ethics with regard to the state in general. According to the Christian view the state is established by God and those who rule must answer to God for the way they rule, whether the concerned government acknowledges this fact or not. The ultimate cure for corruption and bad government is that every person who is involved in government is to fear God and not the people (Fowler, 1988:3). In this sense the concepts of democracy and sound government are not the result of pressure from the industrialized countries of the world or the demands of the general population but find their ultimate origin in a completely different source - the Word of God

A Christian view also implies that a governınent receives its authority from God and should rule with justice. When a state applies its power simply to ensure its ruling position (as is the case with the present Nigerian military regime) it is abusing its power and acting beyond its God-given authority (Fowler, 1988:3)

From a Christian point of view a government (also the Nigerian govermment) is called to see that justice is done to all the sectors of the country's population, that the national income is distributed equally and that smaller ethnic groups are not exploited by larger ethnic groups or by the federal government as such.

From a Christian perspective the link between democratic and responsive government and possible future attempts of secession and self-determination in Nigeria among certain ethnic groups is also relevant in this context. History has clearly shown that the most important and effective measure for preventing secession claims by ethnic groups in plural states is governments which are responsive to and sympathetic towards the particular cultural and socio-economic needs of such groups under its authority. If this principle could be clearly understood by states worldwide a point can be reached where the general problematic of ethnically-divided states would be handled in a politically more satisfactory way. However, it must be remembered that each practical situation is unique and demands unique approaches and management. The principle of responsiveness, however, will always remain relevant in successfully governing multi-cultural societies

It must, however, be conceded that in some cases the creation of independent ethnic states (in a peaceful manner) could provide the possible means by which the problem of plural states could also be approached. It seems as if the spirit of the times and the nature of the present international system could make this option more possible than it would have been during the Cold War period.

\section{Bibliography}

AKE, C. 1993 Nigeria (In The Oxford Companion to Politics of the World New York Oxford University Press. p. 639-649) 
J.F. Kirsten

ANON 1984 Nigeria. (In Worldmark Encyclopedia of the nations: Africa New York : John Wiley. p. 235-246.)

ANON. 1995a. Chaos on two fronts Financial Mail, 136(11):36, Jun 16.

ANON. 1995b. Nigeria. (In Banks, A S. ed. Political Handbook of the World: 1994-1995 New York : CSA Publications p 696-703.)

CASSESE, A 1993. Self-determination ( $I n$ The Oxford Companion to Politics of the World. New York : Oxford University Press. p 822-823.)

COMMONWEALTH SECRETARIAT 1995 Federal Republic of Nigeria (In The Commonwealth Yearbook 1993-94. London : HMSO. p. 315-323.)

FOWLER, S. 1988. The state in the light of the scriptures. Potchefstroom : PU for CHE, Institute for Reformational Studies

GRAF, W.D 1988. The Nigerian State London : James Currey.

HARDEN, B 1993. Africa: Dispatches from a fragile continent. London: Harper Collins

KURIAN, T. 1978. Nigeria. (In Encyclopedia of the Third World London: Mancell. p. 1081-1095)

KWARTENG, C O. 1993. Nigeria's elusive search for nationhood. Africa Insight, 23(1):2435 .

LIEBENOW, J.G 1986. African politics: Crises and challenges. Bloomington : Indiana University Press.

MARENIN, O 1993. Biafra. (In The Oxford Companion to Politics of the World. New York: Oxford University Press. p 79.)

McCASKIE, T C. 1995 Nigeria: recent History. (In Africa South of the Sahara 24th ed London . Europa Publications. p. 693-703.)

MOTALA, Z. 1992. The record of federal constitutions in Africa Africa Law Review. 4(1):3-16, Jul/Aug

ODOGU, E.J 1994. The allurement of ethnonationalism in Nigerian politics: The contemporary debate. Jomrnal of A sian and African Studies, 26(3/4).159-171, July/Oct

PAPP, D.S. 1988. Contemporary international relations Frameworks for understanding. Second Edition. London. Collier Macmillan

SEGAL, B E. 1979. Ethnicity: Where the present is the past (In Raymond, L.H ed. Ethnic autonomy-comparative dynamics New York: Pergamon Press. p. 7-12)

SMITH, G. 1987. Federalism. (III Riff, M.A. ed. Dictionary of modern political ideologies. Manchester : Manchester University Press p. 184-186) 
